\title{
Natural and anthropic pollution episodes during the Late Holocene evolution of the Tinto River estuary (SW Spain)
}

\author{
Marta Arroyo ${ }^{1}$, Francisco Ruiz ${ }^{1,2}$, María Luz González-Regalado 1,2, Joaquín Rodríguez Vidal 1,2, \\ Luis Miguel Cáceres ${ }^{1,2}$, Manuel Olías ${ }^{1}$, Juan Manuel Campos ${ }^{2,3}$, Lucía Fernández ${ }^{2,3}$, Manuel Abad \\ ${ }^{4}$, Tatiana Izquierdo ${ }^{4,5}$, Paula Gómez ${ }^{1,2}$, Antonio Toscano ${ }^{1,2}$, Verónica Romero ${ }^{1}$, Gabriel Gómez ${ }^{1}$

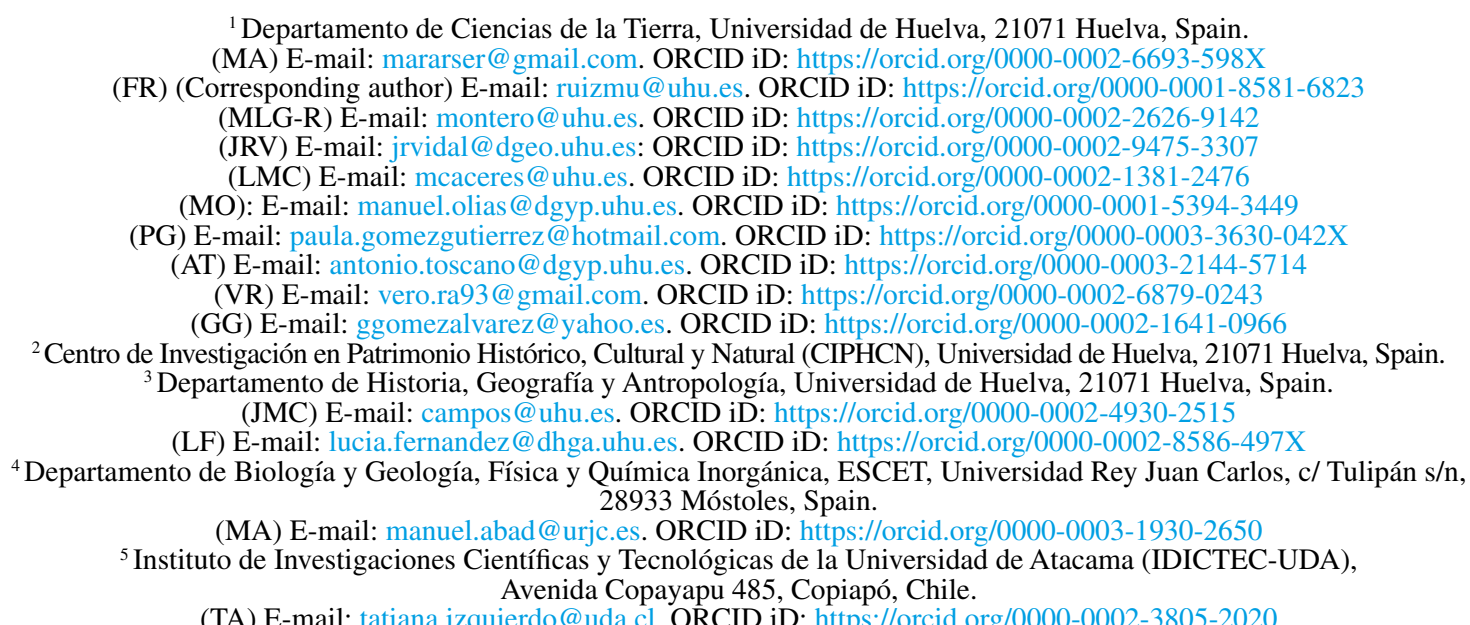

Summary: This paper investigates the paleoenvironmental evolution of a core extracted in the middle sector of the Tinto River estuary, SW Spain, one of the most polluted areas in the world due to mining over thousands of years ( $>4 \mathrm{kyr}$ $\mathrm{BP})$ and recent industrial discharges. This evolution includes alluvial sands ( $>6.4 \mathrm{cal}$ kyr BP), bioclastic sands and silts deposited in subtidal and intertidal channels during and after the Holocene transgression maximum (6.4-4.3 cal kyr BP), the sedimentation of clayey-sandy silts in low and high marshes during the last $2.4 \mathrm{kyr}$ BP and a final anthropic filling. Three sharp peaks of pollution have been detected, representing a) a natural origin during the Holocene transgression; b) the impact of the first mining activities ( $4.5 \mathrm{cal}$ kyr BP $)$; and c) the effect of industrial discharge and a new period of mining activity throughout the 19th and 20th centuries. Foraminifera, ostracods and molluscs disappeared during these last two peaks.

Keywords: pollution; paleoenvironment; biomarkers; Holocene; Tinto estuary; SW Spain.

Episodios de polución natural y antrópica durante la evolución tardiholocena del estuario del río Tinto (SO de España)

Resumen: Este trabajo investiga la evolución paleoambiental inferida a partir del estudio de un testigo extraído en el sector medio del estuario del río Tinto (SO de España), una de las zonas más contaminadas del mundo por actividades mineras milenarias ( $>4 \mathrm{kyr} \mathrm{BP})$ y descargas industriales recientes. Esta evolución incluye arenas aluviales ( $>6.4 \mathrm{cal} \mathrm{kyr} \mathrm{BP})$, arenas bioclásticas y limos depositados en canales submareales e intermareales durante y después del máximo transgresivo holoceno (6.4-4.3 cal kyr BP), la sedimentación de limos arcillosos-arenosos marismeños durante los últimos 2.4 kyr BP y un relleno antrópico final. Se han detectado tres picos de contaminación, que proceden de: a) un origen natural durante el máximo transgresivo holoceno; b) el impacto de las primeras actividades mineras ( $\sim .5 \mathrm{kyr} \mathrm{BP})$; y c) el efecto conjunto de los vertidos industriales y un nuevo período de actividad minera durante los siglos XIX y XX. Los foraminíferos, ostrácodos y moluscos desaparecieron durante estos dos últimos picos.

Palabras clave: polución; evolución paleoambiental; biomarcadores; Holoceno; estuario río Tinto; S.O. España. 
Citation/Como citar este artículo: Arroyo M., Ruiz F., González-Regalado M.L., Rodríguez Vidal J., Cáceres L.M., Olías M., Campos J.M., Fernández L., Abad M., Izquierdo T., Gómez P., Toscano A., Romero V., Gómez G. 2021. Natural and anthropic pollution episodes during the Late Holocene evolution of the Tinto River estuary (SW Spain). Sci. Mar. 85(2): 113-123. https://doi.org/10.3989/scimar.05131.011

Editor: A. Palanques.

Received: September 15, 2020. Accepted: February 22, 2021. Published: May 28, 2021.

Copyright: $(92021$ CSIC. This is an open-access article distributed under the terms of the Creative Commons Attribution 4.0 International (CC BY 4.0) License.

\section{INTRODUCTION}

In the last few decades, numerous investigations have focused on the Holocene paleoenvironmental evolution of coastal areas through multidisciplinary analysis of sediment cores and seismic stratigraphy. In most cases, studying paleoenvironmental evolution involves combining sedimentological, paleontological, geochemical, isotopic and radionuclide techniques (Pascual and Rodríguez Lázaro 2006, Ercilla et al. 2010, Blázquez-Morilla et al. 2018). These studies are used to determine local geochemical backgrounds, with a subsequent application to detecting environmental pollution episodes caused by mining, industrial waste, urban discharges and agricultural activities (Cearreta et al. 2002, Beck et al. 2020).

In the sediment cores, the ecological effects of these episodes have been tested by studying the temporal changes of certain bioindicators, such as bivalves (Mautner et al. 2018), ostracods (review in Ruiz et al. 2005) and benthic foraminifera (Irabien et al. 2008). Species composition, distribution and assemblages of benthic foraminifera are very useful for determining paleoenvironmental changes derived from environmental stress intervals (Cearreta et al. 2000, Romano et al. 2017).

The Tinto estuary is one of the most polluted fluvial-estuarine systems in the world, with very high concentrations of heavy metals (mainly $\mathrm{As}, \mathrm{Cu}, \mathrm{Pb}$ and $\mathrm{Zn}$ ) due to acid mine drainage processes (Lottermoser 2010, Muñoz et al. 2017). The hydrographic basin of this river includes the Iberian Pyrite Belt, one of the largest volcanogenic massive sulphide provinces on Earth, with original resources of about $2000 \mathrm{Mt}$ (Almodóvar et al. 2019). The exploitation of these deposits began during the Tartessian period ( 4.5 kyr BP), with mining of precious metals and copper (Tornos 2008).

Minerals that outcropped or were found at shallow depth were extracted and taken to numerous small facilities (furnaces, crucibles) for metallurgical production (Olías and Nieto 2012). The later Roman period ( 2100$1600 \mathrm{yr}$ BP) saw the first massive exploitation of the Iberian Pyrite Belt, with more than $20 \mathrm{Mt}$ being extracted (Tornos 2008). During this period, more than a hundred mines were exploited, and their dumps and slags were deposited in the river basins, causing a strong environmental impact (Pérez Macías and Delgado 2014).

This exploitation continues today (see review in Olías and Nieto 2015) and has been very intense in the recent period (1850-2001), when about $300 \mathrm{Mt}$ were extracted (Sáinz et al. 2003). The strong environmental pollution caused by the oxidation of mine tailings has increased, with huge spills from industrial discharges produced by two concentrations of chemical industries since 1966 (Fig. 1A-B; Grande et al. 2000). Nevertheless, some studies attribute the current state of the Tinto estuary to natural conditions related to the huge amounts of outcropping sulphides in the upper part of its watersheds (Amils and Fernández-Remolar 2014, Gómez-Ortiz et al. 2014).

This paper carries out a multidisciplinary analysis of a continuous sediment core extracted in the Tinto estuary. The main objectives are (i) to identify and make a paleoenvironmental interpretation of its sedimentary facies; (ii) to reconstruct its paleoenvironmental evolution; (iii) to apply the Miller geoaccumulation index to assess the degree of environmental pollution during the pre-mining period ( $>4500$ years ago), the period from 4500 years ago to the $19^{\text {th }}$ century, the recent period of intensive mining (1870-today), and the industrial period (since 1960); and (iv) to evaluate biomarkers against different degrees of environmental pollution.

\section{MATERIALS AND METHODS}

\section{Study area}

The Tinto River (100 km long) is a small fluvial current that runs in a NE-SW direction through the southwest of the Iberian Peninsula. It shows the typical dynamics of Mediterranean rivers, with highly variable flows depending on the season $\left(<0.1-100 \mathrm{~m}^{3} \mathrm{~s}^{-1}\right.$; Cánovas 2008). This river joins the Odiel River in a wide estuary at its mouth, which is characterized by the presence of two coastal sandy spits (Fig. 1B: Punta Umbría, Punta Arenillas) that protect large internal areas occupied by marshes and old barrier islands that contain cheniers and washover fans (González-Regalado et al. 2018). In this estuary, the tidal regime is mesotidal (2.1 m), with a low diurnal inequality (Borrego et al. 1993).

The interaction between tidal and fluvial inputs divides this estuary into three sedimentary sectors (Pendón 1999): a) the upper estuary, characterized by dominant tidal processes but with clearly fluvial sedimentation (mainly gravels and coarse sands); b) the middle estuary, with meandering channels separated by silty-clayey salt marsh bodies that eventually merge into one main channel, where the river waters $(\mathrm{pH} 2.7-5$; conductivity $0.4-5 \mathrm{mS}$ ) and marine waters $(\mathrm{pH} 7-8.3$; conductivity $>110 \mathrm{mS}$ ) are mixed (Carro et al. 2006), with associated flocculation of fine sediment particles (López-González et al. 2006); and c) the marine estuary, with two main channels dominated by tidal dynamics (Fig. 1B: Padre Santo, Punta Umbría), with bioclastic gravels and sands near the mouth (Ruiz et al. 2000). 


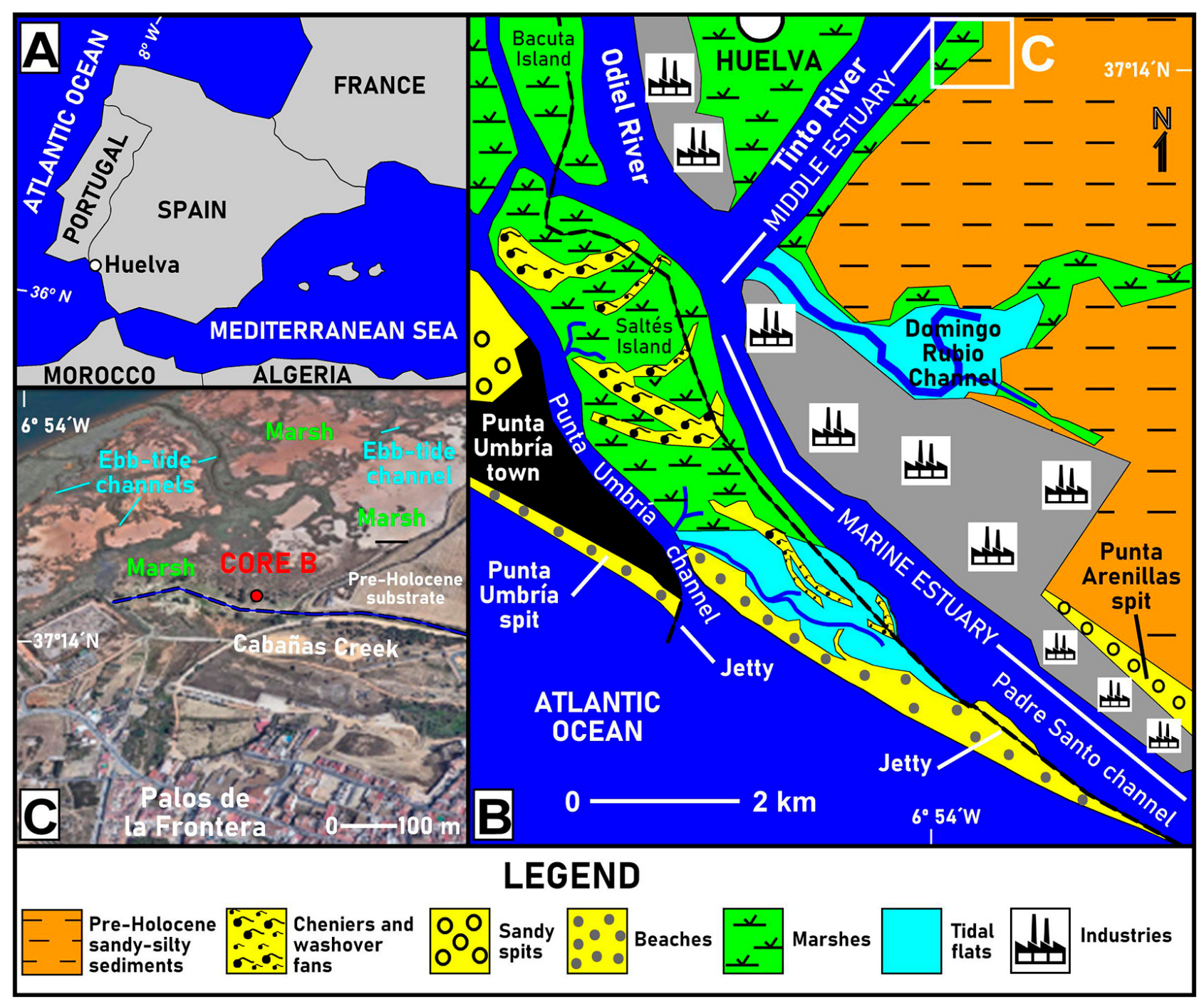

Fig. 1. - A-B, location and geomorphological map of the Tinto River estuary; C, location of core B.

Between 1966 and 1975, two industrial concentrations were located on the estuarine border (Fig. 1B), with the world's largest processing plant for Australian ilmenite black sand (TIOXIDE) and other alkaline, fertilizer and metallurgic plants. From then until 1990, the estuarine pollution from the mining activities was increased by acidic waste from these industrial sources and, to a lesser extent, by urban effluents. The final consequences of this increasing environmental pollution are the presence of very high concentrations of As (up to $3000 \mathrm{mg} \mathrm{kg}^{-1}$ ), $\mathrm{Cu}$ (up to $4415 \mathrm{mg} \mathrm{kg}^{-1}$ ), $\mathrm{Pb}$ (up to $10400 \mathrm{mg} \mathrm{kg}^{-1}$ ) and $\mathrm{Zn}$ (up to $5280 \mathrm{mg} \mathrm{kg}^{-1}$ ) in its surface sediments (Nelson and Lamothe 1993, Usero et al. 1999, Ruiz 2000). Since 1985, this zone has come under a corrective plan for the control of industrial waste disposal.

\section{Coring}

Core B (7.5 m length) was extracted in the transition between the alluvial deposits and the marshes located in the middle estuary of the Tinto River, near the town of Palos de la Frontera (Fig. $1 \mathrm{C} ; 37^{\circ} 14^{\prime} \mathrm{N} ; 6^{\circ} 54^{`} \mathrm{~W}$ ). It was obtained by usual rotary drilling techniques with a continuous recovery of sediment and a barrel diameter of $11.6 \mathrm{~mm}$. Twenty-two samples were collected for a multidisciplinary analysis, according to the visual study of the sedimentary facies and their boundaries. These selected samples cover all sedimentary facies observed in core B and the main bioclastic levels.

\section{Sedimentology}

The visual lithological description was complemented with the grain-size analysis of 18 samples, selected according to the vertical distribution of sedimentary facies. To determine grain-size distribution the coarser fractions were wet-sieved with pressurized water and floated using sieves of $63,125,250500$, 1000 and $2000 \mu \mathrm{m}$ diameter. Fractions smaller than $63 \mu \mathrm{m}$ were analysed with a Mastersizer-2000particle counter at the CIDERTA centre of the University of 
Huelva, Spain. Na-hexametaphosphate was used as a dispersing agent.

\section{Chemical analysis}

The trace metal content of 16 samples was determined and certified by MS Analytical, Langley (Canada). Four trace metals ( $\mathrm{As}, \mathrm{Cu}, \mathrm{Pb}, \mathrm{Zn}$ ) selected as tracers of environmental pollution were obtained by ICP Atomic Emission Spectrometry, with less than $5 \%$ variation between replicate samples and a quality control based on more than 30 sample references (e.g. OREAS 904). In these samples, detection limits were $0.02 \mathrm{mg} \mathrm{kg}^{-1}$ for As, $0.2 \mathrm{mg} \mathrm{kg}^{-1}$ for $\mathrm{Cu}, 0.5 \mathrm{mg} \mathrm{kg}^{-1}$ for $\mathrm{Pb}$ and $2 \mathrm{mg} \mathrm{kg}^{-1}$ for $\mathrm{Zn}$. The geoaccumulation index $\left(\mathrm{I}_{\text {geo }}\right.$; Muller 1969) was applied in order to define the environmental pollution in sediments (e.g. Li et al. 2016, Al Mukaimi et al. 2018, Yan et al. 2020). This index is calculated as follows:

$$
\mathrm{I}_{\text {geo }}=\log _{2}\left(\frac{\mathrm{C}_{\mathrm{n}}}{1.5 \mathrm{~B}_{\mathrm{n}}}\right) \text {, }
$$

where $C_{n}$ is the measured concentration in a sample for the metal $n, B_{n}$ is the background value for the metal $n$ in the study area and factor 1.5 is used because of possible variations of the background data due to lithological variations. This index defines six pollution categories: $\mathrm{I}_{\text {geo }}<1$ (unpolluted); $1<\mathrm{I}_{\text {geo }}<2$ (very low polluted); $2<\mathrm{I}_{\mathrm{geo}}<3$ (low polluted); $3<\mathrm{I}_{\mathrm{geo}}<4$ (moderately polluted); $4<\mathrm{I}_{\text {geo }}<5$ (heavily polluted); and $\mathrm{I}_{\text {geo }}>5$ (very heavily polluted).

$I_{\text {geo }}$ is vulnerable to distortion by grain-size effects. Consequently, a double regional background of the Tinto-Odiel estuary (Ruiz et al. 1998) was used for (i) silty-clayey sediments (As, $7.3 \mathrm{mg} \mathrm{kg}^{-1} ; \mathrm{Cu}, 13 \mathrm{mg}$ $\mathrm{kg}^{-1} ; \mathrm{Pb}, 15.4 \mathrm{mg} \mathrm{kg}^{-1} ; \mathrm{Zn}, 39 \mathrm{mg} \mathrm{kg}^{-1}$ ); and (ii) sandy sediments (As, $6.8 \mathrm{mg} \mathrm{kg}^{-1} ; \mathrm{Cu}, 13.1 \mathrm{mg} \mathrm{kg}^{-1} ; \mathrm{Pb}, 4.3$ $\left.\mathrm{mg} \mathrm{kg}{ }^{-1} ; \mathrm{Zn}, 15.9 \mathrm{mg} \mathrm{kg}^{-1}\right)$.

\section{Palaeontology}

Eighteen samples were selected for microfaunistic analysis. In each sample, 20 grams of sediment were separated and levigated through a $125 \mu \mathrm{m}$ mesh sieve. This sieve was selected for three reasons: a) it retains practically all of the malacofauna for which sieves with a larger mesh diameter are usually used $(\geq 250 \mu \mathrm{m}$ mesh diameter in most cases; Alexandrowicz 2017, Cristini and De Francesco 2017); b) the benthic foraminiferal assemblages picked from this fraction provide useful information on prevailing environmental conditions that is useful for an overview of paleoenvironmental changes in coastal settings (Lo Giudice Capelli and Austin 2019), two of the main objectives of this paper; and c) this sieve is suitable for screening the ostracod fauna and preventing the presence of juveniles of these microcrustaceans (stages $1-4$ ), which are very difficult to identify (Danielopol et al. 2002).

The residue was dried in an oven at a constant temperature of $40^{\circ} \mathrm{C}$ for a period of no less than one day.
The total populations of molluscs (bivalves and gastropods) were determined according to Gómez (2017) and the World Register of Marine Species (WoRMS). The microfaunal content (foraminifera and ostracods) was also extracted and determined. Foraminifera were classified according to Loeblich and Tappan (1987), Milker and Schmiedl (2012) and WoRMS. Ostracoda were classified according to Ruiz et al. (1997, 2000). This micropaleontological record was compared with (i) the assemblages of both groups present in the Neogene formations found in the vicinity of core B (González-Regalado and Ruiz 1996, Ruiz and González-Regalado 1996), in order to identify reworked specimens; and (ii) a database of the distribution of the two groups in the estuaries of southwestern Spain (Ruiz et al. 2000, González-Regalado et al. 2001), which was used to recognize paleoenvironmental changes or anthropogenic impacts in this core. These studies analysed the foraminiferal and ostracod assemblages of the main sedimentary facies of these estuaries (high salt marsh, low salt marsh, ebb-tide channel, main channel, tidal plain and beach).

\section{Dating}

Two dates were produced at the National Centre of Accelerators (CNA, Seville, Spain), with a subsequent calibration using CALIB version 7.1 and the reservoir effect correction $\left(-108 \pm 31{ }^{14} \mathrm{C}\right.$ yr) calculated by Martins and Soares (2013) for this area. The final results correspond to calibrated ages using $2 \sigma$ intervals. The mean calibrated ages (MCA) were used to produce a chronological framework of core B. They were completed with the comparison between the vertical geochemical variations and the main periods of mining extraction and industrial discharges (see Introduction), in order to obtain additional age references.

\section{RESULTS}

\section{Sedimentary facies and macrofauna}

The lowermost $1.2 \mathrm{~m}$ of core B (Fig. 2; facies F1: 7.5-6.3 m depth) are composed of similar percentages of sands and silts (35-45\%), with minor contributions of clays $(<18 \%)$ and scarce gravels. This interval does not contain macrofauna. This absence contrasts with the abundance of mollusc fragments observed in the overlying $1.4 \mathrm{~m}$ (F2: 6.3-4.9 $\mathrm{m}$ depth), consisting of bioclastic sands and gravels with silty intercalations containing frequent vegetable remains. In this facies, a total of 162 specimens were determined belonging to four species of bivalves and four species of gastropods. Two macrofaunistic assemblages were recognized: a) the gastropods Bittium reticulatum (da Costa, 1778) and Peringia ulvae (Pennant, 1777) and the bivalves Ruditapes decussatus Linnaeus, 1758 and Cerastoderma glaucum (Brugiére, 1789), which were very abundant especially in bioclastic gravels (Fig. 2: 5.7-5.4 m depth); and b) the gastrod Bittium reticulatum and the bivalves Ostrea ostentina Payraudeau, 1826, C. glaucum and Cerastoderma edule (Linnaeus, 1758), which 
CORE B

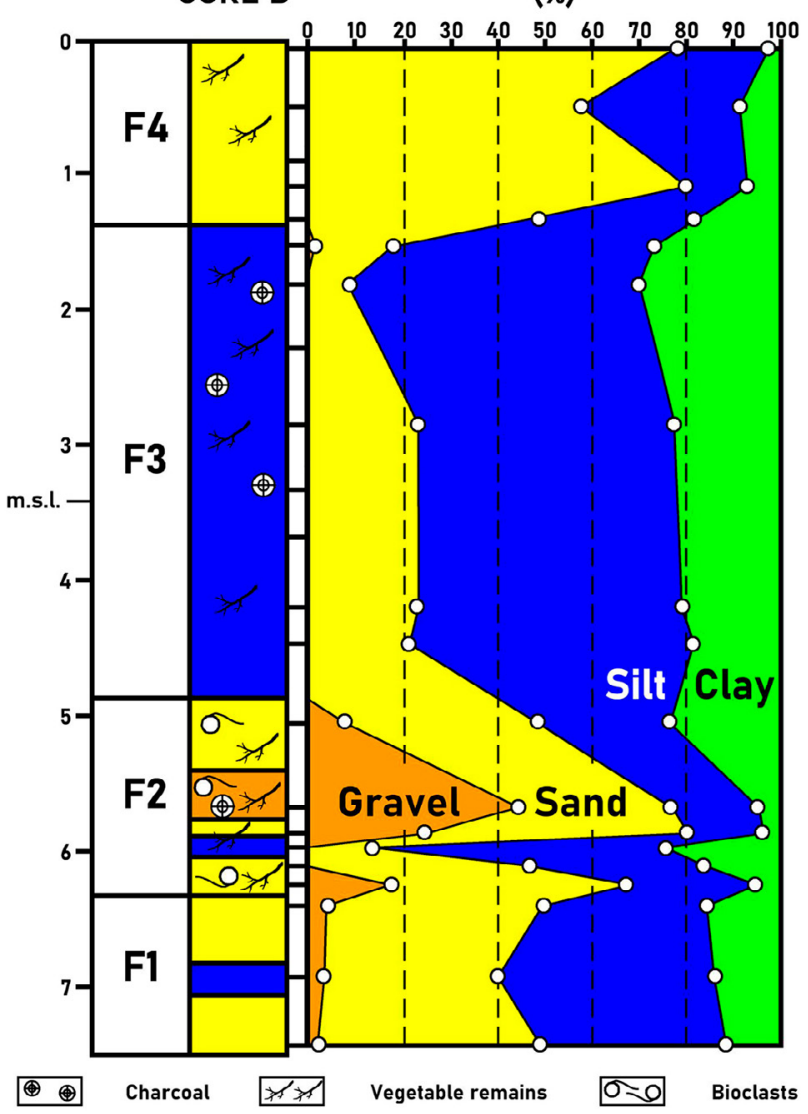

were well represented in the uppermost bioclastic sands of this facies (5.4-4.9 m depth).

The third sedimentary facies of core B (F3: 4.9-1.4 $\mathrm{m}$ depth) is represented by sandy silts (silt, 54\%-63\%; sand, 9\%-22\%) with frequent fragments of charcoal, stems and roots. Macrofauna is also absent in this facies, which is replaced by fine silty sands with frequent vegetable remains in the upper 1.4 metres of the core (F4).

\section{Geochemistry}

The heavy metal pollution profiles of core B reveal the four sedimentary facies, with the differentiation of three pollution levels (Fig. 3). F1 is characterized by low to very low concentrations of the four measured elements, including some of the lowest values of core B (Fig. 3: As $<8 \mathrm{mg} \mathrm{kg}^{-1} ; \mathrm{Cu}<22 \mathrm{mg} \mathrm{kg}^{-1} ; \mathrm{Pb}<15 \mathrm{mg}$ $\mathrm{kg}^{-1} ; \mathrm{Zn}<35 \mathrm{mg} \mathrm{kg}^{-1}$ ). Similar contents were also measured in the bioclastic levels of F2, which contrast with the first peak (Fig. 3: FPL) observed in the intercalated silts. In these fine sediments, As $\left(27 \mathrm{mg} \mathrm{kg}^{-1}\right), \mathrm{Cu}(39$ $\left.\mathrm{mg} \mathrm{kg}{ }^{-1}\right), \mathrm{Pb}\left(74 \mathrm{mg} \mathrm{kg}^{-1}\right)$ and $\mathrm{Zn}\left(93 \mathrm{mg} \mathrm{kg}^{-1}\right)$ are considerably higher.

F3 is characterized by very low to low concentrations of these heavy metals (e.g. As $<20 \mathrm{mg} \mathrm{kg}^{-1}$; $\mathrm{Cu}<25 \mathrm{mg} \mathrm{kg}^{-1}$ ). This facies includes a second relative maximum at $4.2 \mathrm{~m}$ depth (Fig. 3: SPL), with As $(30 \mathrm{mg}$ $\left.\mathrm{kg}^{-1}\right), \mathrm{Cu}\left(52 \mathrm{mg} \mathrm{kg}^{-1}\right)$ and $\mathrm{Zn}\left(107 \mathrm{mg} \mathrm{kg}^{-1}\right)$ as the most representative trace elements of this new peak. However, the highest contents of all these trace elements (As, $44 \mathrm{mg} \mathrm{kg}^{-1} ; \mathrm{Cu}, 284 \mathrm{mg} \mathrm{kg}^{-1}$; $\mathrm{Mn}$ and $\mathrm{Pb}, 98 \mathrm{mg} \mathrm{kg}^{-1}$; $\mathrm{Zn}, 539 \mathrm{mg} \mathrm{kg}^{-1}$ ) were measured at 2 to $1.4 \mathrm{~m}$ depth,

Fig. 2. - Textural analysis of core B.

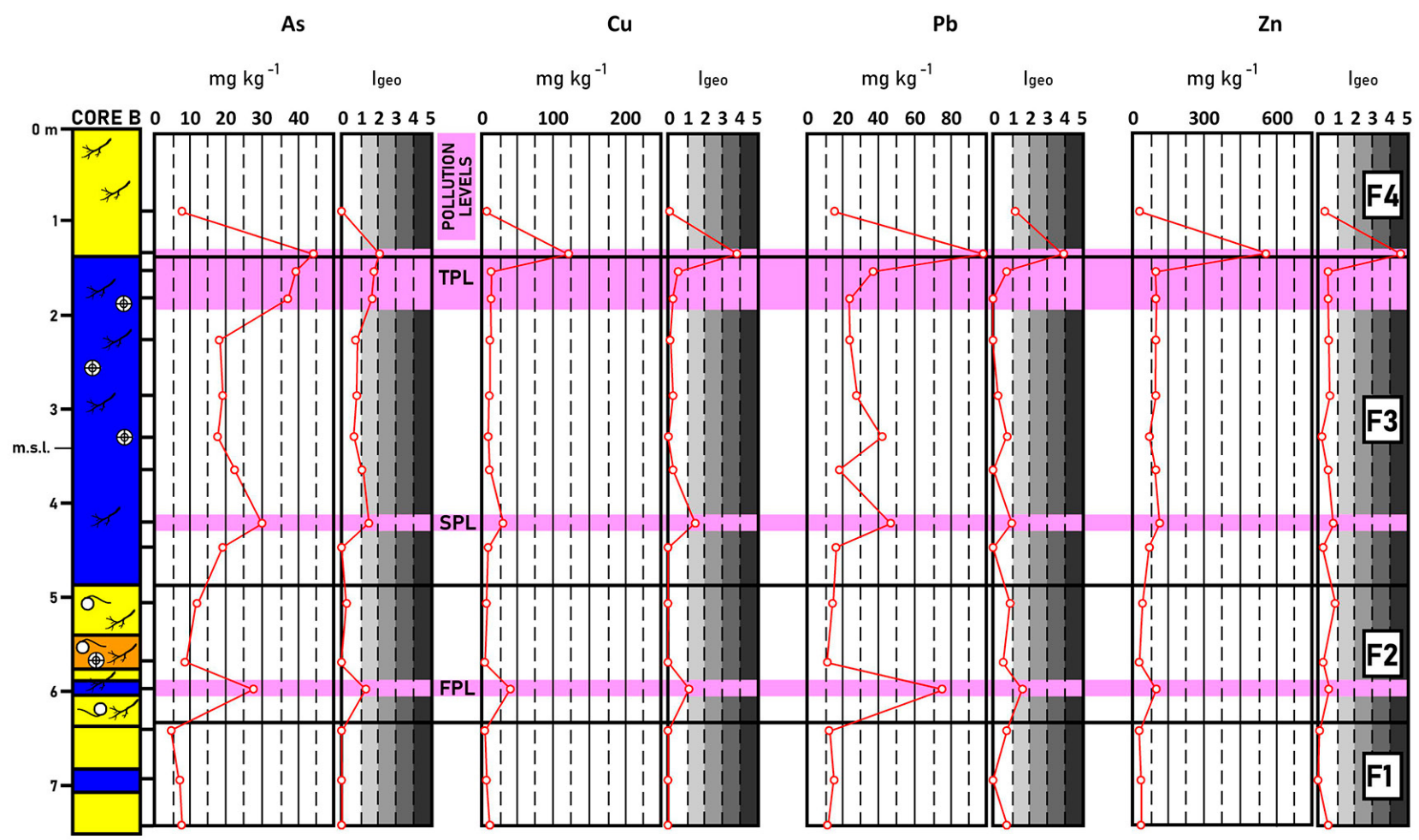

Fig. 3. - Geochemistry of core B (in $\mathrm{mg} \mathrm{kg}^{-1}$ ). FPL: first pollution level; SPL: second pollution level; TPL: third pollution level. 
with the highest contents near the transition between F3 and F4 (Fig. 3: TPL). This sandy facies has a geochemical signal very similar to that of F1.

The geoaccumulation index clearly identifies the three pollution peaks, and especially TPL (Fig. 3). The first pollution peak (FPL) is defined by very low pollution levels for all four investigated metals $\left(1 \leq \mathrm{I}_{\text {geo }} \leq 1.68\right)$, while similar geoaccumulation indices $\left(1.02 \leq \mathrm{I}_{\text {geo }} \leq 1.83\right)$ were detected during the second pollution peak (SPL). The highest values of $I_{\text {geo }}$ were obtained during the third pollution peak (TPL), with sediments moderately or heavily polluted by $\mathrm{Zn}\left(\mathrm{I}_{\text {geo }}\right.$ up to 4.5$), \mathrm{Pb}\left(\mathrm{I}_{\text {geo }}\right.$ up to 3.9$)$ and $\mathrm{Cu}$ ( $\mathrm{I}_{\text {geo }}$ up to 3.9). This pollution was weakest for As $\left(1.74 \leq \mathrm{I}_{\mathrm{geo}_{0}} \leq 2.1\right)$ during this last peak. The remaining samples were unpolluted, except $\mathrm{F} 4$ for $\mathrm{Pb}\left(\mathrm{I}_{\mathrm{geo}}=1.2\right)$.

\section{Microfauna and other groups}

A total of 1839 shells of benthic foraminifera belonging to 11 Holocene species (1395 specimens) and 27 Neogene reworked species (444 specimens) were extracted from the 18 samples studied, with more than $99 \%$ of the individuals concentrated in F2 (Fig. 4). In this facies, both Holocene (25-35 ind. g) and Neogene (up to 16 ind. g) foraminifera are abundant.

The Holocene record of these microorganisms starts at the uppermost sandy levels of $F 1$, with rare specimens of Ammonia tepida (Cushman, 1926). This species is very abundant in the upper bioclastic gravels and sands of F2 (994 ind./60 g), together with Ammonia beccarii (Linnaeus, 1758), Haynesina depressula (Walker and Jacob, 1798) and Haynesina germanica (Ehrenberg, 1840). These species (Fig. 5) were found together with the scarce ostracods extracted in this core [Fig. 4: Leptocythere fabaeformis (Mueller, 1894) and Loxoconcha rhomboidea (Fisher, 1855)]. Few specimens of A. tep$i d a$ and $A$. beccarii characterize the silty levels of this facies. This facies also contains a considerable number of Neogene species (Fig. 5), the most representative ones being Nonion commune (d'Orbigny, 1846), Bulimina elongata (d'Orbigny, 1826), Fursenkoina acuta (d'Orbigny, 1846), Globobulimina affinis (d'Orbigny, 1839), Melonis pompilioides (Fichtel and Moll, 1798) and Marginulinopsis costata (Bastch, 1791). Echinoderm spines are also very abundant in F2.

Three foraminiferal zones are differentiated within F3 (Fig. 4): a) the basal zone (F3a), characterized by the disappearance of all the previous groups coinciding with the second pollution peak; b) the intermediate zone (F3b), with only specimens of Trochammina inflata (Montagu, 1808) ( $<5$ ind./20 g), an agglutinated-walled foraminifera; and c) the upper zone (F3c), represented by the exclusive presence of Entzia macrescens (Brady, 1870), another agglutinated-walled foraminifera $(<5$ ind./20 g). Charcoal and small plant remains (stems, roots) are abundant in the two upper

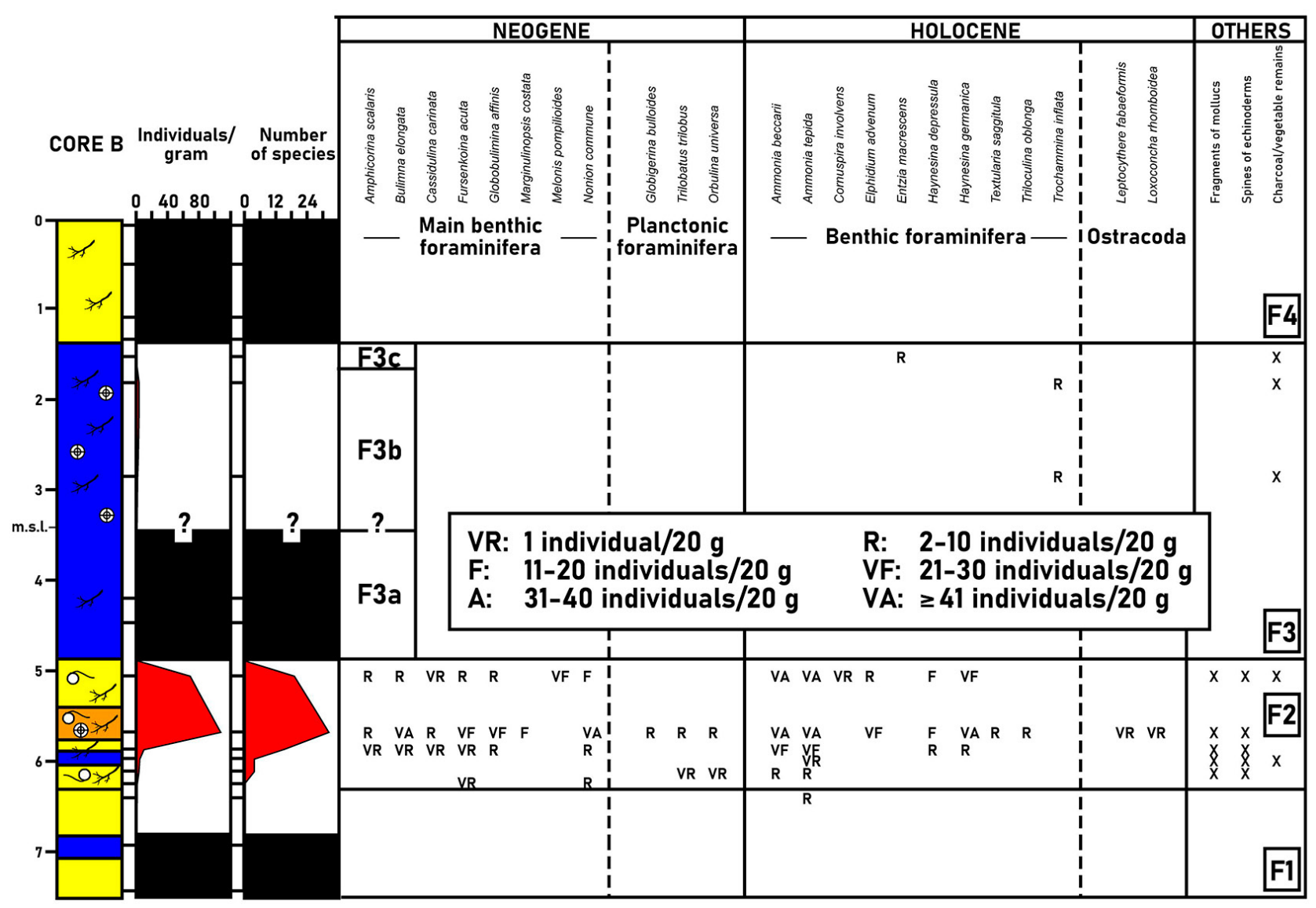

Fig. 4. - Palaeontological record of core B. 
HOLOCENE BIVALVES

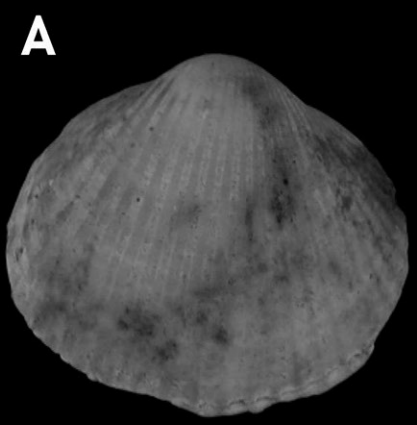

Cerastoderma edule
B

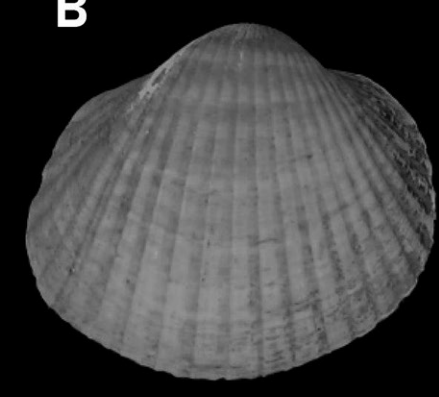

Cerastoderma glaucum

\section{HOLOCENE GASTROPODS}

C

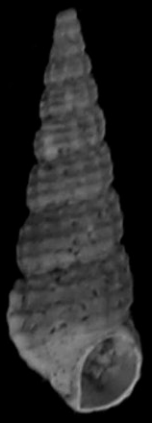

Bittium reticulatum
D

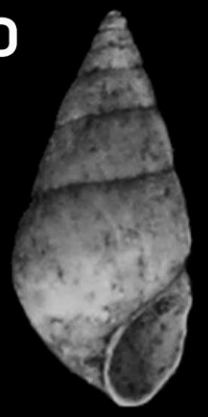

Peringia ulvae

\section{HOLOCENE FORAMINIFERA}

E

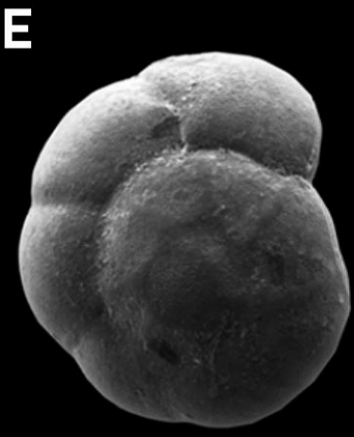

Ammonia inflata

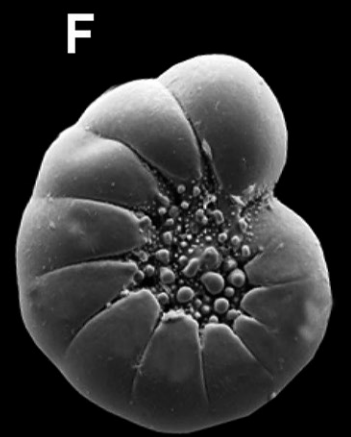

Haynesina germanica
G
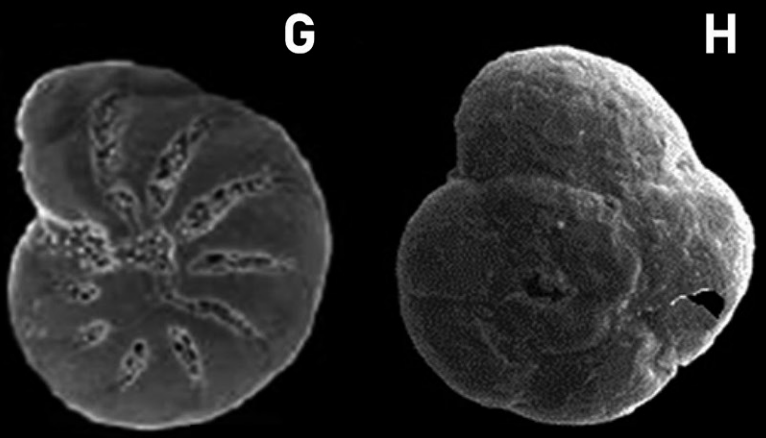

NEOGENE FORAMINIFERA

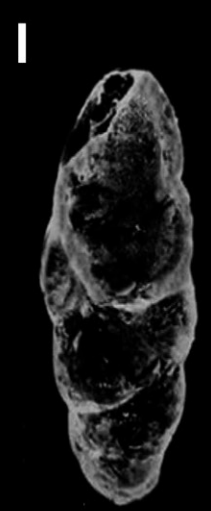

Bulimina elongata

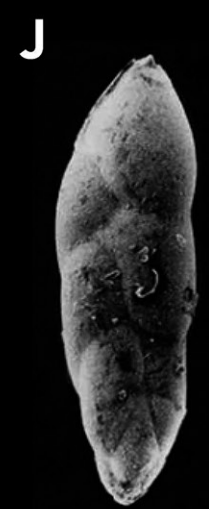

Fursenkoina acuta
$\mathrm{K}$

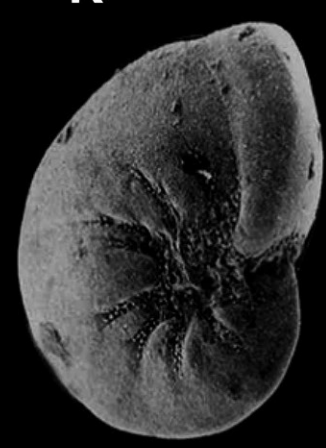

Nonion commune
HOLOCENE OSTRACODA

Haynesina depressula Trochammina inflata 
zones. Foraminifera, ostracods, other faunal groups and plants were not found from the transition between F3 and F4 (e.g. TPL) and the top of core B.

\section{Dating}

Two dates were obtained from two levels, at depths of $6 \mathrm{~m}$ (sample CNA-4274; organic matter; 5892-5711 cal yr BP; MCA 5.8 cal kyr BP) and $5.7 \mathrm{~m}$ (sample CNA-4272; shell; C. edule; 5483-5368 cal yr BP; MCA 5.4 cal kyr BP).

\section{DISCUSSION}

\section{Sedimentary facies: paleoenvironmental interpretation}

The silty-sandy sediments of F1 are characterized by the very low concentrations of all the elements analysed, as well as the absence of fauna and plant remains. This facies is interpreted as alluvial deposits, which probably originated from erosive action of the Tinto River drainage network. Of these all deposits, the Cabañas creek is still preserved in the studied sector (Fig. 1C). Its geochemical signal is similar to that measured in nearby Pleistocene to Holocene fluvial sediments of the Tinto River (Cáceres et al. 2013).

The lower and middle bioclastic gravels and sands of F2 (Fig. 4: 6.3-5.4 m depth) include an assemblage of Holocene molluscs (Bittium, Peringia and Ruditapes), benthic foraminifera (mainly Ammonia and Haynesina genera), ostracods (Leptocythere and Loxoconcha genera) and fragments of echinoderms typical of shallow subtidal ebb-tide channels or sandy tidal flats with variable salinity and partially vegetated bottoms (Ruiz et al. 2000, González-Regalado et al. 2001).

In the uppermost sandy layers of this facies (5.4-4.9 $\mathrm{m}$ depth), the increasing presence of cockles (C. glaucum, $C$. edule) and the decreasing density and diversity of foraminifera (Fig. 4) point to a partial restriction of tidal inputs and a decrease in water depth, with a transition to an intertidal, very shallow channel with brackish waters. The silty intercalations probably correspond to a transition to the border of this channel (Gómez 2017, Ordiales et al. 2017). The presence of abundant Neogene foraminifera involves the simultaneous erosion of the adjacent Mio-Pliocene formations (González-Regalado and Ruiz 1996, Ruiz and González-Regalado 1996). Some of these Neogene foraminifera currently live in the adjacent Gulf of Cádiz, mainly at depths of 30 to $100 \mathrm{~m}$ (e.g. B. elongata; Mendes et al. 2012), but they have not been found in the middle zones of the adjacent estuaries (González-Regalado et al. 2001).

The few species of benthic foraminifera found in F3 are characteristic of marshes (see Murray 2006 for a review). T. inflata, the most representative species of $\mathrm{F} 3 \mathrm{~b}$, is more common in low salt marshes, while $E$. macrescens $(\mathrm{F} 3 \mathrm{c})$ is usually more abundant in high salt marshes (González-Regalado et al. 2001, Jones 2014). No foraminifera were found in F3a and F4. This facies corresponds to the anthropic filling of the area during the last third of the 20th century.

\section{Paleoenvironmental evolution of core B: pollution,} fauna and sea level

The two dates obtained in F2 indicate the deposit of $0.3 \mathrm{~m}$ of bioclastic sediments in about 400 years, with a mean sedimentation rate of $0.75 \mathrm{~mm} \mathrm{yr}^{-1}$. If this average rate is extrapolated to the entirety of $F 2$, the base of this sedimentary facies was deposited around $6.4 \mathrm{cal}$ kyr BP (Fig. 6). The age of its lower limit coincides with the flooding of this estuary during the beginning of the Holocene transgression maximum $(\sim 6.5 \mathrm{cal} \mathrm{kyr}$ BP; Zazo et al. 1994), clearly contrasted by the determined fauna (see the previous section). This would indicate that a) the deposit of basal alluvial sediments (F1) would have occurred before $\sim 6.4$ cal kyr BP; b) the transit from subtidal to intertidal paleoenviroments took place around 5.3 cal kyr BP ago within F2; and c) the maximum of the Holocene transgression caused the flooding of this area and the first episod of natural pollution (FPL), clearly reflected within the finest sediments of this facies (Fig. 3). This peak is one of the oldest episodes of natural pollution in southwestern Europe and has been detected in other cores of the Tinto River estuary (Arroyo et al. 2021). This small peak may be due to the coincidence of the Holocene flooding and the weathering/oxidation of the mineral deposits concentrated in the Iberian Pyrite Belt, a process that began in the Oligocene (Essalhi et al. 2011).

F3 includes a moderate pollution peak at $4.2 \mathrm{~m}$ depth (SPL) and the highest concentrations of trace metals at $1.4 \mathrm{~m}$ depth (TPL). According to the previous datings and the sedimentation rates obtained by Lario et al. (2002) in this estuary, the first of them is attributed to the first mining activities in this area (4.7-4.5 cal kyr BP; Rothenberg and Blanco Freijero 1980, Olías and Nieto 2015).

The uppermost peak is due to the conjunction of intensive mining and industrial discharges during the 19th and 20th centuries (Ruiz 2000, Ruiz et al. 2009).

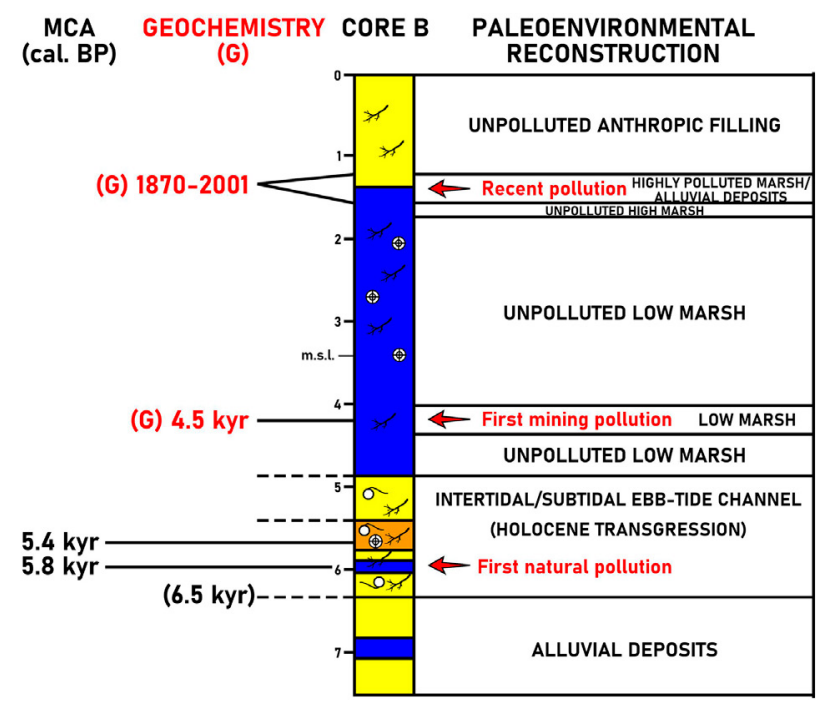

Fig. 6. - Paleoenvironmental evolution of core B. MCA: mean calibrated age. 
Both episodes of pollution coincide with the disappearance of all the faunal groups studied (Fig. 4). This negative impact of pollution on the assemblages of molluscs, foraminifera and ostracods has been contrasted in different littoral environments (Armenteros et al. 2016, Reddy et al. 2016) and may even cause the disappearance of these groups (Ruiz et al. 2000, González-Regalado et al. 2001).

The time interval between these two episodes witnessed a period of silting, with the transition from a low salt marsh to a high salt marsh in recent centuries (Fig. $6)$. During the intermediate stage with little mining and industrial activity, the foraminiferal record of this period is very similar to that observed in undisturbed salt marshes (Jones 2014, Soualili 2018, Haller et al. 2019). No evidence of Roman mining pollution ( 2.1-1.5 cal kyr BP) has been found in this core, as in other cores of this estuary (e.g. Leblanc et al. 2000). This absence may be due to a) an erosion of the Roman deposits in this fluvial context; or b) the location and paleoenvironmental evolution of these cores, which may include sediments deposited in emerged areas during Roman times. Finally, the upper sandy layer (F4) comes from the anthropic filling of this sector in the last 30 years.

The correlation with other cores collected in the middle estuary of the Tinto River estuary (Ruiz et al. 2020, Arroyo et al. 2021) can be used to obtain a synthetic paleoenvironmental evolution of this sector since the Upper Pleistocene, with four main phases: a) the Upper Pleistocene, when the fluvial network eroded the Neogene marine formations and created several coves on a Miocene substrate; b) the Lower Holocene (ca. 10-6.5 kyr BP), with the deposits of alluvial, sandy sediments: c) the Holocene transgression (ca. $6.5 \mathrm{kyr}-5.4$ kyr BP), with the flooding of this area and the transport of marine bioclastic sands towards the innermost zones of the estuary; and d) the Late Holocene (ca. $5.4 \mathrm{kyr}$ $\mathrm{BP}$ ), with the development of wide salt marshes and the fit of the main channels.

\section{CONCLUSIONS}

A multidisciplinary analysis of a core extracted in the middle estuary of the Tinto River was used to reconstruct the paleoenvironmental evolution of this sector from the period prior to the Holocene transgression maximum to the present. Prior to $\sim 6.4 \mathrm{cal}$ kyr BP, this area was occupied by sandy alluvial deposits, which were flooded by the rise of the sea level during this maximum. These fluvial sediments gave way to bioclastic sands and gravels that were deposited at the bottom of subtidal and intertidal channels, owing to the flooding of this sector during the maximum of the Holocene transgression. The water fluxes caused the first peak of pollution, which reflects natural contamination before the start of mining activities in the adjacent Iberian Pyrite Belt.

The upper $3.5 \mathrm{~m}$ of natural filling (4.9-1.4 $\mathrm{m}$ depth) was deposited in low and high salt marshes, according to their foraminiferal assemblages. These salt marshes include two new peaks of pollution, which are attributed to the first mining activities ( 4.5 cal kyr BP) and the joint action of recent mining (since 1870) and additional discharges from nearby industrial complexes (since 1960). A comparison with other cores of this middle estuary reveals the synthetic paleoenvironmental evolution of this sector from the Pleistocene fluvial environments to significant silting during the last ca. 5.4 kyr BP, with intermediate flooding during the Holocene transgression (ca. 6.5-5.4 kyr BP).

\section{ACKNOWLEDGEMENTS}

This work was mainly financed by the Palos de la Frontera Council. It was also carried out through the following projects: a) DGYCIT project CTM200606722/MAR; b) DGYCIT project CGL2006-01412; c) From the Atlantic to the Tyrrhenian. The Hispanic ports and their commercial relations with Ostia Antica. DEATLANTIR II - HAR2017-89154-P - (Plan Nacional de I+D+i); and d) FEDER 2014-2020 project UHU-1260298. Other funds were obtained from Andalusian Government (groups HUM-132, RNM-238 and RNM-293). This paper is a contribution to the Research Centre in Historical, Cultural and Natural Heritage (CIPHCN) of the University of Huelva.

\section{REFERENCES}

Al Mukaimi M.E., Kaiser K., Williams J.R., et al. 2018. Centennial record of anthropogenic impacts in Galveston Bay: Evidence from trace metals $(\mathrm{Hg}, \mathrm{Pb}, \mathrm{Ni}, \mathrm{Zn})$ and lignin oxidation products. Environ. Pollut. 237: 887-899. https://doi.org/10.1016/j.envpol.2018.01.027

Alexandrowicz W.P. 2017. Malacofauna of the Holocene tufa in the valleys of the Ociemny Stream (Pieniny Mts, southern Poland. Geol., Geoph. Environ. 43: 5-18. https://doi.org/10.7494/geol.2017.43.1.5

Almodóvar G.R., Yesares L., Sáez R., et al. 2019. Massive sulfide ores in the Iberian Pyrite Belt: mineralogical and textural evolution. Minerals 9: 653. https://doi.org/10.3390/min9110653

Amils R., Fernández-Remolar D. 2014. The IPBSL Team. Río Tinto: A geochemical and mineralogical terrestrial analogue of Mars. Life 4: 511-534. https://doi.org/10.3390/life4030511

Armenteros M., Díaz-Asencio M., Fernández-Garcés R., et al. 2016. One-century decline of mollusk diversity as consequence of accumulative anthropogenic disturbance in a tropical estuary (Cuban Archipelago). Mar. Pollut. Bull. 113: 224-231. https://doi.org/10.1016/j.marpolbul.2016.09.023

Arroyo M., Ruiz F., Campos J.M., et al. 2021. Where did Christopher Columbus start?: The estuarine scenario of a historical date. Estuar., Coast. Shelf Sci. 250: 107162. https://doi.org/10.1016/j.ecss.2020.107162

Beck K.K., Mariani M., Fletcher M.-S., et al. 2020. The impacts of intensive mining on terrestrial and aquatic ecosystems: A case of sediment pollution and calcicum decline in cool températe Tasmania, Australia. Environ. Pollut. 265: 114695 . https://doi.org/10.1016/j.envpol.2020.114695

Blázquez-Morilla A.M., Rodríguez-Pérez A., Sanjuán-Lamata D. 2018. Palaeoenvironmental evolution from the early Holocene to the present of the Almenara marsh (western Mediterranean). Sci. Mar. 82: 257-268. https://doi.org/10.3989/scimar.04853.07A

Borrego J., Morales J.A., Pendón J.G. 1993. Holocene flling of an estuarine lagoon along the mesotidal coast of Huelva: The Piedras River mouth, southwestern Spain. J. Coast. Res. 9: 242-254.

Cáceres L.M., Olías M., de Andrés J.R., et al. 2013. Geochemistry of Quaternary sediments in terraces of the Tinto River (SW Spain): Paleoenvironmental implications. 
Catena 101: 1-10

https://doi.org/10.1016/j.catena.2012.09.011

Cánovas C.R. 2008. La calidad del agua de los ríos Tinto y Odiel. Evolución temporal y factores condicionantes de la movilidad de los metales. PhD thesis, Universidad de Huelva, 425 pp.

Carro B., Borrego J., López-González N., et al. 2006. Procesos de mezcla de un estuario afectado por drenaje de aguas ácidas (Ría de Huelva, España). Geogaceta 39: $115-118$.

Cearreta A., Irabien M.J., Leorri E., et al. 2000. Recent anthropogenic impacts on the Bilbao Estuary, Northern Spain: Geochemical and Microfaunal Evidence. Estuar. Coast. Shelf Sci. 50: 571-592. https://doi.org/10.1006/ecss.1999.0582

Cearreta A., Irabien M.J., Leorri E., et al. 2002. Environmental transformation of the Bilbao estuary, N. Spain: microfaunal and geochemical proxies in the recent sedimentary record. Mar. Pollut. Bull. 44: 487-503. https://doi.org/10.1016/S0025-326X(01)00261-2

Cristini P.A., De Francesco C.G. 2017. Molluscan taphonomy patterns below the sediment-water interface in freshwater shallow lakes from the southeastern Pampa plain, Argentina. Palaios 32: 528-542. https://doi.org/10.2110/palo.2016.081

Danielopol D.L., Ito E., Wansard G., et al. 2002. Techniques for Collection and Study of Ostracoda. In: Holmes J.A., Chivas A.R. (eds), The Ostracoda: Applications in Quaternary Research, Geophysical Monograph Series 131, The American Geophysical Union, pp. 65-97. https://doi.org/10.1029/131GM04

Ercilla G., Estrada F., Casas D., et al. 2010. The El Masnou infralittoral sedimentary environment (Barcelona province, NW Mediterranean Sea): morphology and Holocene seismic stratigraphy. Sci. Mar. 74: 179-196. https://doi.org/10.3989/scimar.2010.74n1179

Essalhi M., Sizaret S., Barbanson L., et al. 2011. A case study of the internal structures of gossans and weathering processes in the Iberian Pyrite Belt using magnetic frabrics and paleomagnetic dating. Miner. Depos. 46: 981-999. https://doi.org/10.1007/s00126-011-0361-8

Gómez G. 2017. Guía de los moluscos marinos de Huelva y el Golfo de Cádiz. Diputación de Huelva, Huelva, 300 pp.

Gómez-Ortiz D., Fernández-Remolar D.C., Granda A., et al. 2014. Identification of the subsurface sulfide bodies responsible for acidity in Río Tinto source water, Spain. Earth Planet. Sci. Lett. 391: 36-41. https://doi.org/10.1016/j.epsl.2014.01.022

González-Regalado M.L., Ruiz F., 1996. Les foraminiféres benthiques de la baie du sud-ouest de l'Espagne pendant le Néogène supérieur: le Mio-Pliocène de Huelva. Rév. Paléobiol. 15: 109-120.

González-Regalado M.L., Ruiz F., Baceta J.I., et al. 2001. Total benthic foraminifera assemblages in the southwestern Spanish estuaries. Geobios 34: 39-51. https://doi.org/10.1016/S0016-6995(01)80042-5

González Regalado M.L., Gómez P., Ruiz F., et al. 2018. Holocene palaeoenvironmental evolution of Saltés Island (Tinto and Odiel estuary, SW Spain) during the Roman period (1 st century BC-5th century AD). J. Iber. Geol. 45: $129-145$. https://doi.org/10.1007/s41513-018-0089-8

Grande J.A., Borrego J., Morales J.A. 2000. A study of heavy metal pollution in the Tinto-Odiel estuary in southwestern Spain using factor analysis. Environ. Geol. 39: 1095-1101. https://doi.org/10.1007/s002549900080

Haller C., Smith C.G., Hallock P., et al. 2019. Distribution of Modern Salt-marsh Foraminifera from the Eastern Mississippi Sound, U.S.A. J. Foram. Res. 49: 29-47. https://doi.org/10.2113/gsjfr.49.1.29

Irabien M.J., Cearreta A., Leorri E., et al. 2008. A 130 year record of pollution in the Suances estuary (southern Bay of Biscay): Implications for environmental management. Mar. Pollut. Bull. 56: 1719-1727. https://doi.org/10.1016/j.marpolbul.2008.07.006

Jones R.W. 2014. Foraminifera and their applications. Cambridge University Press, Cambridge, $448 \mathrm{pp}$.

Lario J., Zazo C., Goy J.L., et al. 2002. Changes in sedimentation trends in SW Iberia Holocene estuaries (SW Spain). Quat. Int. 93-94: 171-176.
https://doi.org/10.1016/S1040-6182(02)00015-0

Leblanc M., Morales J.A., Borrego J., et al. 2000. 4,500-year-old mining pollution in southwestern Spain: long-term implications for modern mining pollution. Econ. Geol. 95: 655-662. https://doi.org/10.2113/gsecongeo.95.3.655

Li L., Cui J., Liu J., et al. 2016. Extensive study of potential harmful elements (Ag, As, Hg, Sb, and Se) in surface sediments of the Bohai Sea, China: Sources and environmental risks. Environ. Pollut. 219: 432-439. https://doi.org/10.1016/j.envpol.2016.05.034

Lo Giudice Capelli E., Austin W.E.N. 2019. Size Matters: Analyses of Benthic Foraminiferal Assemblages Across Differing Size Fractions. Front. Mar. Sci. 6: 752. http://doi.org/10.3389/fmars.2019.00752

Loeblich A.R., Tappan H. 1987. Foraminiferal Genera and Their Classification. Van Nostrand Rienhold Co., New York, 2013 pp. https://doi.org/10.1007/978-1-4899-5760-3

López-González N., Morales J.A., Borrego J., et al. 2006. Variación estacional de las características texturales en los sedimentos intermareales de los estuarios de los ríos Tinto y Odiel (S.O. de España). Geogaceta 40: 291-294.

Lottermoser B.G. 2010. Mine wastes: Characterization, Treatment and Environmental Impacts. Springer-Verlag, Berlin, $277 \mathrm{pp}$.

Martins J.M.M., Soares A.M.M. 2013. Marine radiocarbon reservoir effect in Southern Atlantic Iberian coast. Radiocarbon 55: 1123-1134. https://doi.org/10.1017/S0033822200048037

Mautner A.K., Gallmetzer I., Haselmair A., et al. 2018. Holocene ecosystem shifts and human-induced loss of Arca and Ostrea shell beds in the north-eastern Adriatic Sea. Mar. Pollut. Bull. 126: 19-30. https://doi.org/10.1016/j.marpolbul.2017.10.084

Mendes I., Alveirinho Dias J., Schönfeld J., et al. 2012. Distribution of living benthic foraminifera on the northern Gulf of Cádiz. J. Foram. Res. 42: 18-38. https://doi.org/10.2113/gsifr.42.1.18

Milker Y., Schmiedl G., 2012. A taxonomic guide to modern benthic shelf foraminifera of the western Mediterranean Sea. Palaeont. Elect. 15: 16A. https://doi.org/10.26879/271

Muller G. 1969. Index of geoaccumulation in sediments of the Rhine River. Geojournal 2: 108-118.

Muñoz S., Cambrollé J., Castillo J.M., et al. 2017. Handling high soil trace elements pollution: case study of the Odiel and Tinto Rivers Estuary and the accompanying salt marshes (southwestern Iberian Peninsula). In: Finkl C.W., Makowski C. (eds), Coastal Wetlands: Alteration and Remediation, Springer, pp. 215-241. https://doi.org/10.1007/978-3-319-56179-0_7

Murray A.E. 2006. Ecology and Applications of Benthic Foraminifera. Cambridge University Press, New York, 426 pp. https://doi.org/10.1017/CBO9780511535529

Nelson C.H., Lamothe P.J. 1993. Heavy metal anomalies in the Tinto and Odiel River and estuary system, Spain. Estuaries 16: 496-511. https://doi.org/10.2307/1352597

Olías M., Nieto J.M. 2012. El impacto de la mineríaen los ríos Tinto y Odiel a lo largo de la historia. Rev. Soc. Geol. España 25: 177-192.

Olías M., Nieto J.M. 2015. Background conditions and mining pollution throughout history in the Rio Tinto (SW Spain). Environments 2: 295-316. https://doi.org/10.3390/environments2030295

Ordiales A Martínez-García B., Mendioca J 2017. Distribución y ecología de las asociaciones de foraminíferos bentónicos del estuario del Oriñón (E de Cantabria, $N$ de la Península Ibérica). Geogaceta 61: 131-134.

Pascual A., Rodríguez Lázaro J. 2006. Marsh development and sea level changes in the Guernika Estuary (southern Bay of Biscay): foraminifers as tidal indicators. Sci. Mar. 70S1: 101-117. https://doi.org/10.3989/scimar.2006.70s110

Pendón J.G. 1999. La costa de Huelva. Una introducción a los procesos y productos sedimentarios. Universidad de Huelva, Huelva, $198 \mathrm{pp}$.

Pérez Macías J.A., Delgado A. 2014. La minería en el suroeste ibérico. CPAG 24: 239-265. https://doi.org/10.18259/acs.2014028 
Reddy B.C.S.R., Jayaraju N., Sreenivasulu G., et al. 2016. Heavy metal pollution monitoring with foraminifera in the estuaries of Nellore coast, East coast of India. Mar. Pollut. Bull. 113: 542-551.

https://doi.org/10.1016/j.marpolbul.2016.08.051

Romano E., De Giudici G., Bergamin L., et al. 2017. The marine sedimentary record of natural and anthropogenic contribution from the Sulcis-Iglesiente mining district (Sardinia, Italy). Mar. Pollut. Bull. 122: 331-343. https://doi.org/10.1016/j.marpolbul.2017.06.070

Rothenberg B., Blanco Freijero A. 1980. Ancient copper mining and smelting at Chinflon. In: Craddock P.T. (ed.), Scientific studies in early mining and extractive metallurgy, British Museum, London, pp. 41-62.

Ruiz F. 2000. Trace metals in estuarine sediments from the southwestern Spanish coast. Mar. Pollut. Bull. 42: 482-490. https://doi.org/10.1016/S0025-326X(00)00192-2

Ruiz F., González-Regalado M.L. 1996. Les ostracodes du Golfe Mio-Pliocene du sud-ouest de l'Espagne. Rév. Micropaléont. 39: 137-151. https://doi.org/10.1016/S0035-1598(96)90038-0

Ruiz F., González-Regalado M.L., Muñoz J.M. 1997. Multivariate analysis applied to total and living fauna: seasonal ecology of recent benthic Ostracoda off the North Cádiz Gulf coast (southwestern Spain). Mar. Micropal. 31: 183-203. https://doi.org/10.1016/S0377-8398(96)00060-6

Ruiz F., González-Regalado M.L., Borrego J., et al. 1998. Stratigraphic sequence, elemental concentrations and heavy metal pollution in Holocene sediments from the Tinto-Odiel Estuary, southwestern Spain. Environ. Geol. 34: 270-278. https://doi.org/10.1007/s002540050278

Ruiz F., González-Regalado M.L., Baceta J.I., et al. 2000. Comparative ecological analysis of the ostracod faunas from lowand high-polluted southwestern Spanish estuaries: a multivariate approach. Mar. Micropal. 40: 345-376. https://doi.org/10.1016/S0377-8398(00)00048-7

Ruiz F., Abad M., Bodergat A.M., et al. 2005. Marine and brackish-water ostracods as sentinels of anthropogenic impacts. Earth-Sci. Rev. 72: 89-111. https://doi.org/10.1016/j.earscirev.2005.04.003

Ruiz F., Borrego J., González-Regalado M.L., et al. 2009. Interaction between sedimentary processes, historical pollution and microfauna in the Tinto estuary (SW Spain). Environ. Geol. 58: 779-783.

https://doi.org/10.1007/s00254-008-1551-2

Ruiz F., Rodríguez Vidal, J., Cáceres, L.M., et al. 2020. Silver and copper as pollution tracers in Neogene to Holocene estuarine sediments from southwestern Spain. Mar. Pollut. Bull. 150: 110704 https://doi.org/10.1016/j.marpolbul.2019.110704

Sáinz A., Grande J.A., de la Torre M.L. 2003. Analysis of the impact of local corrective measures on the input of contaminants from the Odiel river to the ria of Huelva (Spain). Water Air Soil Pollut. 144: 375-389. https://doi.org/10.1023/A:1022905502320

Soualili K. 2018. El registro sedimentario antropoceno enel estuario del Deba (Geoparque de la Costa Vasca). CKQ-Est. Cuat. 8: 147-165.

Tornos F. 2008. La Geología y Metalogenia de la Faja Pirítica Ibérica. Macla 10: 13-23.

Usero J., Morillo J., Gracia I. 1999. Heavy metals in sediments from the Tinto River (Spain). IMWA Proceedings 1999: 243-246.

World Register of Marine Species (WoRMS). http://www.marinespecies.org/. Last revision: March 16, 2020.

Yan Y., Chi H., Liu J., et al. 2020. Provenance and bioaccessibility of rare earth elements in atmospheric particles in areas impacted by the optoelectronic industry. Environ. Pollut. 263: 114349 . https://doi.org/10.1016/j.envpol.2020.114349

Zazo C., Goy J.L., Somoza L, et al. 1994. Holocene sequence of sea-level fluctuations in relation to climatic trends in the Atlantic-Mediterranean linkage coast. J. Coast. Res. 10: 933-945. 